\title{
The spider genera Azerithonica and Tegenaria (Aranei: Agelenidae: Tegenariini) in Iran
}

\section{Пауки родов Azerithonica и Tegenaria (Aranei: Agelenidae: Tegenariini) Ирана}

\author{
Alireza Zamani ${ }^{1^{*}}$, Yuri M. Marusik ${ }^{2,3}$ \\ А. Замани ${ }^{1^{*}}$ Ю.М. Марусик ${ }^{2,3}$ \\ ${ }^{1}$ Zoological Museum, Biodiversity Unit, University of Turku, FI-20014, Finland. \\ ${ }^{2}$ Institute for Biological Problems of the North RAS, Portovaya Str.18, Magadan, Russia. \\ ${ }^{3}$ Department of Zoology \& Entomology, University of the Free State, Bloemfontein 9300, South Africa. \\ ${ }^{2}$ Институт биологических проблем Севера ДВО РАН, Магадан 685000 Россия. \\ * Corresponding author: zamani.alireza5@gmail.com
}

KEY WORDS: Araneae, new species, fauna, new records, revision.

КЛЮЧЕВЫЕ СЛОВА: Araneae, новый вид, фауна, новая находка, ревизия.

ABSTRACT: Two Tegenariini genera occurring in Iran, Azerithonica Guseinov, Marusik et Koponen, 2005 and Tegenaria Latreille, 1804 are revised. As a result, the former genus and its type species, Azerithonica hyrcanica Guseinov, Marusik et Koponen, 2005 are recorded in Iran for the first time. A new species, $A$. sagartia sp.n. ( + , Mazandaran) is described from northern Iran, representing the second species of Azerithoni$c a$, enabling us to provide an updated diagnosis for the genus. Furthermore, six new species of Tegenaria are described from western and northern Iran, namely: $T$. arsacia sp.n. ( + , Hamedan), T. daylamanica sp.n. ( + , Gilan), T. eros sp.n. (+, Golestan), T. guseinovi sp.n. ( + , Kermanshah), T. rahnamayi sp.n. ( + , Mazandaran) and $T$. shirin sp.n. ( $\sigma^{T}$, Kermanshah). In addition, $T$. halidi Guseinov, Marusik et Koponen, 2005, previously known from Azerbaijan only, is newly recorded for the fauna of Iran, and new distribution records are provided for $T$. domestica (Clerck, 1757), T. lenkoranica Guseinov, Marusik et Koponen, 2005 and T. pagana C.L. Koch, 1840. With the exception of the widelydistributed and well-known $T$. domestica and T. paga$n a$, all of the remaining species are illustrated, and known distributions of Azerithonica spp. and all Iranian Tegenaria spp. are mapped.

How to cite this article: Zamani A., Marusik Yu.M. 2019. The spider genera Azerithonica and Tegenaria (Aranei: Agelenidae: Tegenariini) in Iran // Arthropoda Selecta. Vol.28. No.2. P.291-303. doi: 10.15298/ arthsel. 28.2.12

РЕЗЮМЕ. Ревизованы два рода трибы Tegenariini обитающие в Иране, Azerithonica Guseinov, Marusik et Koponen, 2005 и Tegenaria Latreille, 1804. Род Azerithonica и его типовой вид A. hyrcanica Guseinov, Marusik et Koponen, 2005 впервые указаны для Ирана. Из северного Ирана описан новый вид A. sagartia sp.n. (†, Мазандаран), это второй вид рода ранее считавшийся монотипичным. Находка нового вида позволила уточнить диагноз рода. Описано шесть новых видов Tegenaria из западного и северного Иран: T. arsacia sp.n. (†, Хамадан), T. daylamanica sp.n. ( + , Гилян), T. eros sp.n. ( ${ }_{+}$, Голестан), T. guseinovi sp.n. (, Керманшах), T. rahnamayi sp.n. (†, Мазандаран) и T. shirin sp.n. ( $\sigma^{7}$, Керманшах). Tegenaria halidi Guseinov, Marusik et Koponen, 2005, ранее известная из Азербайджана впервые указывается для Ирана. Приведены новые данные по распространению в стране $T$. domestica (Clerck, 1757), T. lenkoranica Guseinov, Marusik et Koponen, 2005 и T. pagana C.L. Koch, 1840. Bce виды проиллюстрированы за исключение двух самых распространённых и хорошо изученных $T$. domestica и T. pagana. Точки находок всех видов прокартированны.

\section{Introduction}

Agelenidae is a species rich and globally-distributed spider family comprising 1307 species in 82 genera [WSC, 2019]. In Iran, this family is currently represented by nine species in four genera [Zamani et al., 2019]. Tegenaria Latreille, 1804, primarily distributed in the Palaearctic is the second largest genus of the family with 106 valid species. This genus is currently very poorly studied in Iran, with only five recorded species, two of which are regional endemics [WSC, 2019]. The fauna and taxonomy of Agelenidae in neighboring Azerbaijan and Turkey are much better studied due to regional revisions (e.g. Marusik et al., 2005) or a series of faunistic-taxonomic papers by Brignoli [1972, 1978a,b] and some other recent authors.

Recently, we've had the opportunity to study the material collected by the late Antoine Senglet from 
different parts of Iran. Among this material we found several species of Tegenariini new to science and a genus (Azerithonica Guseinov, Marusik et Koponen, 2005) and two species previously not recorded from Iran. The goal of this paper is to provide a review of Tegenariini occurring in Iran.

\section{Material and methods}

This paper is mostly based on material collected by A. Senglet in Iran, which is stored in the Muséum d'histoire naturelle, Genève, and material collected by the junior author in 2000, which is temporarily housed in the Zoological Museum of University of Turku, Finland. Specimens were photographed using a Canon EOS 7D camera attached to an Olympus SZX16 stereomicroscope or to the eye piece of an Olympus BH2 transmission microscope at the Zoological Museum of University of Turku. Digital images were prepared using "CombineZP" image stacking software (http:// www.hadleyweb.pwp.blueyonder.co.uk/). Illustrations of the endogyne were made after clearing in a $10 \% \mathrm{KOH}$ aqueous solution followed by exposure for a few minutes in an alcohol/water solution of Chlorazol Black. Lengths of leg segments were measured on the dorsal side. Measurements of legs are listed as: total length (femur, patella, tibia, metatarsus, tarsus). Spination of metatarsi are given as total number without specifying spine position. All measurements are given in millimeters. Global distributions are according to the WSC [2019], and regional distribution data are from Zamani et al. [2019]. The depositories of the studied material are the Muséum d'histoire naturelle, Genève, Switzerland (MHNG) and the Zoological Museum of Moscow University, Moscow, Russia (ZMMU).

Abbreviations. Eyes: ALE - anterior lateral eye, AME - anterior median eye, PLE - posterior lateral eye, PME - posterior median eye. Female copulatory organs: $A d$ - anterior part of ducts, $A r$ - accessorial receptacle, $C d$ - copulatory ducts, $R e$ - receptacle, $R g$ - receptacular gland, $S c$ - scape. Male copulatory organs: $P c-$ posterior branch of conductor, $V l-$ ventrolateral tibial apophysis. Spination: $d-$ dorsal, $F e-$ femur, $M t-$ metatarsus, $P a$ - patella, $P l$ - prolateral, $R l$ - retrolateral, $T i-$ tibia, $v$ - ventral.

\section{Taxonomy}

\section{Genus Azerithonica Guseinov, Marusik et Koponen, 2005}

TYPE SPECIES. Azerithonica hyrcanica Guseinov, Marusik et Koponen, 2005 from southeastern Azerbaijan.

COMMENTS. Prior to this paper, the genus was considered monotypic and endemic to southern Azerbaijan [Mikhailov, 2013; Otto, 2014; WSC, 2019]. With the finding of a new species, we are now able to update the diagnosis of the genus.

DIAGNOSIS. The genus well differs from all other Tegenariini by a long and sharply pointed posterior branch of the conductor extending the proximal part of the tegulum $(P c$, Figs 2I, K) vs. a short, often bifurcated conductor which does not extend the proximal part of the tegulum. Females of Azerithonica differ from other Tegenariini by their long copulatory ducts forming several loops and the presence of "accessorial" receptacles (Ar: Figs 2A-D, G, H) located anteriorly ( $v s$. copulatory ducts short or even indistinct, or if ducts are long, "accessorial" receptacles absent).

COMPOSITION. Two species, A. hyrcanica $\left(\mathrm{O}^{\top}+\right)$ and A. sagartia sp.n. (+).

DISTRIBUTION. The genus is known from southeastern Azerbaijan to central-western Mazandaran, northern Iran (511'ㄹ, Map 1).

\section{Azerithonica hyrcanica Guseinov, Marusik et Ko- ponen, 2005}

Figs 2E-K, Map 1.

Azerithonica hyrcanica Guseinov et al., 2005: 159, f. 26-36, $111-113\left(\mathrm{O}^{\top}+\right)$.

MATERIAL EXAMINED. IRAN: Gilan Province: 2 우 (NHMG), Pareh-Sar, 373'N, 49 $03^{\prime}$ E, 2.07 .1973 (A. Senglet); 2 우 (NHMG), near Djavaherdeh, 1200 m, 7.08.1974 (A. Senglet); 1 (NHMG), Asalem, $37^{\circ} 45^{\prime} \mathrm{N}, 48^{\circ} 57^{\prime} \mathrm{E}, 11.06 .1975$ (A. Senglet); 1 o (NHMG), Lunak, $37^{\circ} 03^{\prime} \mathrm{N}, 49^{\circ} 55^{\prime} \mathrm{E}, 600 \mathrm{~m}, 6.07 .1973$ (A. Senglet); 1 + (NHMG), Asalem, $37^{\circ} 40^{\prime} \mathrm{N}, 48^{\circ} 52^{\prime} \mathrm{E}, 1200 \mathrm{~m}, 10.06 .1975$

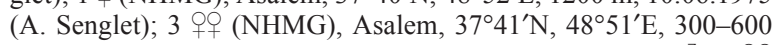
m, 30.06.1973 (A. Senglet); Mazandaran Province: $10^{7} 2$ 우 (ZMMU), $\mathrm{N}$ of Javaher-Deh Vil. ( $\sim 500 \mathrm{~m}$ below vil. by elevation), $36^{\circ} 52^{\prime} \mathrm{N}, 50^{\circ} 28^{\prime} \mathrm{E}, 9.06 .2000$ (Yu.M. Marusik); 2 우 (ZMMU), Tooban, env. of Khorramabad Vil., $36^{\circ} 43^{\prime} \mathrm{N}, 50^{\circ} 48^{\prime} \mathrm{E}, 8-10.06 .2000$ (Yu.M. Marusik).

DIAGNOSIS. This species differs from A. sagartia sp.n., a species known from the holotype female only, by having a widened and transparent anterior part of the copulatory ducts ( $A c$; close to copulatory openings) and the copulatory ducts do not form coils $v s$. all ducts of the same diameter coiled several times (cf. Figs 2A-D and 2E-H).

DESCRIPTION. Described by Guseinov et al. [2005].

RECORDS IN IRAN. Gilan, Mazandaran (current data).

DISTRIBUTION. This species is known from southeasternmost Azerbaijan, east to Mazandaran, almost $51^{\circ} \mathrm{E}$ (first record in Iran) (Map 1).

\section{Azerithonica sagartia sp.n.}

Figs 1B, 2A-D, Map 1.

TYPE MATERIAL. Holotype 9 (NHMG), Iran: Mazandaran Province: Pol-e Zanguleh, $36^{\circ} 13^{\prime} \mathrm{N}, 51^{\circ} 19^{\prime} \mathrm{E}, 2300 \mathrm{~m}, 10.07 .1974$ (A. Senglet).

ETYMOLOGY. This species is named after the Sagartians, an ancient tribe dwelling in the Iranian plateau.

DIAGNOSIS. The new species differs from the generotype, A. hyrcanica, by the shape of the epigyne: copulatory openings indistinct ( $v s$. distinct), copulatory ducts of the same diameter along entire course, forming coils (vs. anterior part of ducts $(A d)$ widened, and ducts not coiled).

DESCRIPTION. Female. Total length 4.26. Carapace 1.64 long, 1.29 wide. Eye sizes and interdistance: AME: 0.05, ALE: 0.09, PME: 0.10, PLE: 0.12, PME-PME: 0.06. Carapace, sternum, labium, chelicerae, and maxillae light brown, without any pattern. Legs the same color as the carapace, without any annulations. Abdomen light gray without any pattern. Spinnerets uniform in color and slightly lighter than the abdomen. Leg I measurements: 7.85 (2.02, $0.71,1.97,1.91,1.24)$. Spination: leg I: Fe 2d, 2pl, Mt 6; leg II: Fe 2d, 1pl, Pa 1d, Ti 1d, 1pl, 2v, Mt 6; leg III: Fe 2d, 1pl, 2rl, Pa 1d, Ti 1d, 2pl, 2rl, Mt 9; leg IV: Fe 2d, 1pl, Ti 2pl, 2rl, 1v, Mt 8.

Epigyne as in Figs 2A-D. Scape $(S c)$ wider than long, as wide as distance between copulatory openings. Copulatory 

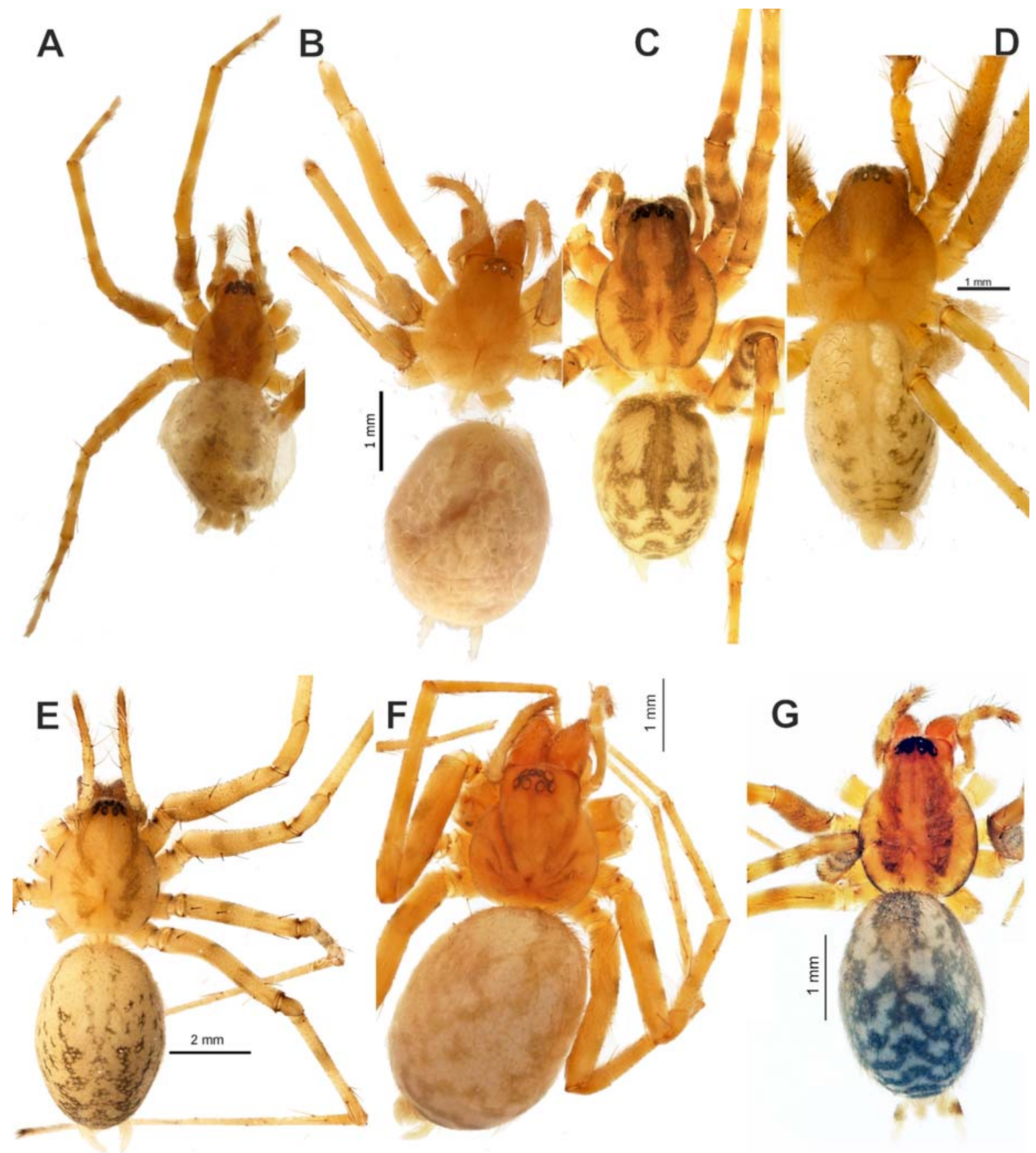

Fig. 1. Habitus of holotypes of Tegenaria arsacia sp.n. (A), Azerithonica sagartia sp.n. (B), T. eros sp.n. (C), T. shirin sp.n. (D), T. guseinovi sp.n. (E), T. daylamanica sp.n. (F) and T. rahnamayi sp.n. (G). A-C, E-G - females, dorsal; D - male, dorsal.

Рис. 1. Внешний вид голотипов Tegenaria arsacia sp.n. (А), Azerithonica sagartia sp.n. (B), T. eros sp.n. (C), T. shirin sp.n. (D), T. guseinovi sp.n. (E), T. daylamanica sp.n. (F) и T. rahnamayi sp.n. (G). A-C, E-G - самка, сверху; D - самец, сверху.

openings indistinct, separated by 2.5 diameters of the receptacles; copulatory ducts long, with several coils, and ducts of the same diameter along the entire course; span of receptacles wider than span of copulatory ducts.

Male. Unknown.

DISTRIBUTION. Known only from the type locality in Mazandaran Province, northern Iran (Map 1). This is the southeasternmost record of the genus in the entire range.
Genus Tegenaria Latreille, 1804

TYPE SPECIES. Tegenaria domestica (Clerck, 1757). COMMENTS. Tegenaria is second largest genus in the family and largest in Tegenariini. Judging from the significant variation in the shape of epigynes and male palps, Tegenaria is most likely paraphyletic, if not polyphyletic [Bolzern et al., 2013]. 

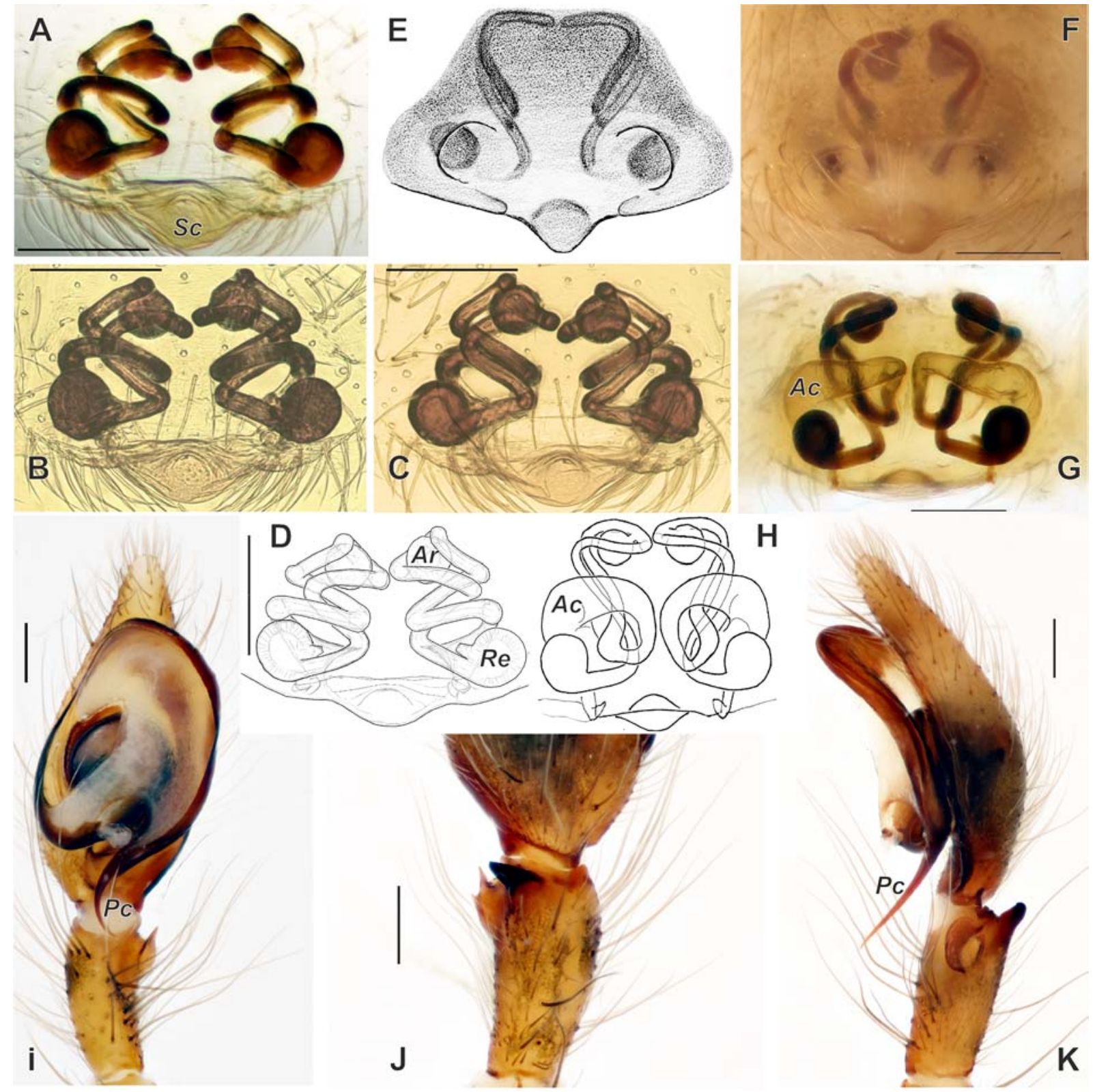

Fig. 2. Copulatory organs of Azerithonica sagartia sp.n. (A-D) and A. hyrcanica (E-K). A-B, D, G-H - epigyne, dorsal; C, E-F epigyne, ventral; I-K - male palp, ventral, dorsal and retrolateral. A and B showing the same aspect but made by different microscopes. E after Marusik et al. [2005]. Scale $=0.2 \mathrm{~mm}$, if indicated.

Abbreviations: $A c$ - anterior part of copulatory ducts, $A r-$ accessorial receptacle, $P c-$ posterior branch of conductor, $R e-$ receptacle, $S c$ - scape.

Рис. 2. Копулятивные органы Azerithonica sagartia sp.n. (A-D) и A. hyrcanica (E-K). А-B, D, G-H - эпигина, сверху; C, E-F эпигина, снизу; I-K - пальпа самца, снизу, сверху и ретролатерально. А и В показана одна и та же эпигина снятая разными микроскопами. Е - по Marusik et al. [2005]. Масштаб = 0,2 мм, если указан.

Сокращения: $A c$ - передняя часть копулятивных протоков, $A r$ - дополнительная рецептакула, $P c$ - задняя часть кондуктоpa, $R e$ - рецептакула, $S c$ - скапус.

Tegenaria alamto Zamani, Marusik et MalekHosseini, 2018

Figs 3A, 5E-G, Map 2.

Tegenaria alamto Zamani et al., 2018a: 95, f. 1-11 ( $0^{7}+$ ). DIAGNOSIS. Males of this species differ from other Tegenaria from the Middle East by the short embolus form- ing almost a right angle and also by the thin, bill-like tip of the posterior branch of the conductor $(P c)$. Females of $T$. alamto differ from other congeners by elongate receptacles, a lack of distinct copulatory ducts and the presence of epigynal teeth (Figs 5E-G). Another species, T. guseinovi sp.n. with epigynal teeth, has very long and membranous copulatory ducts (Figs 7A-H). 


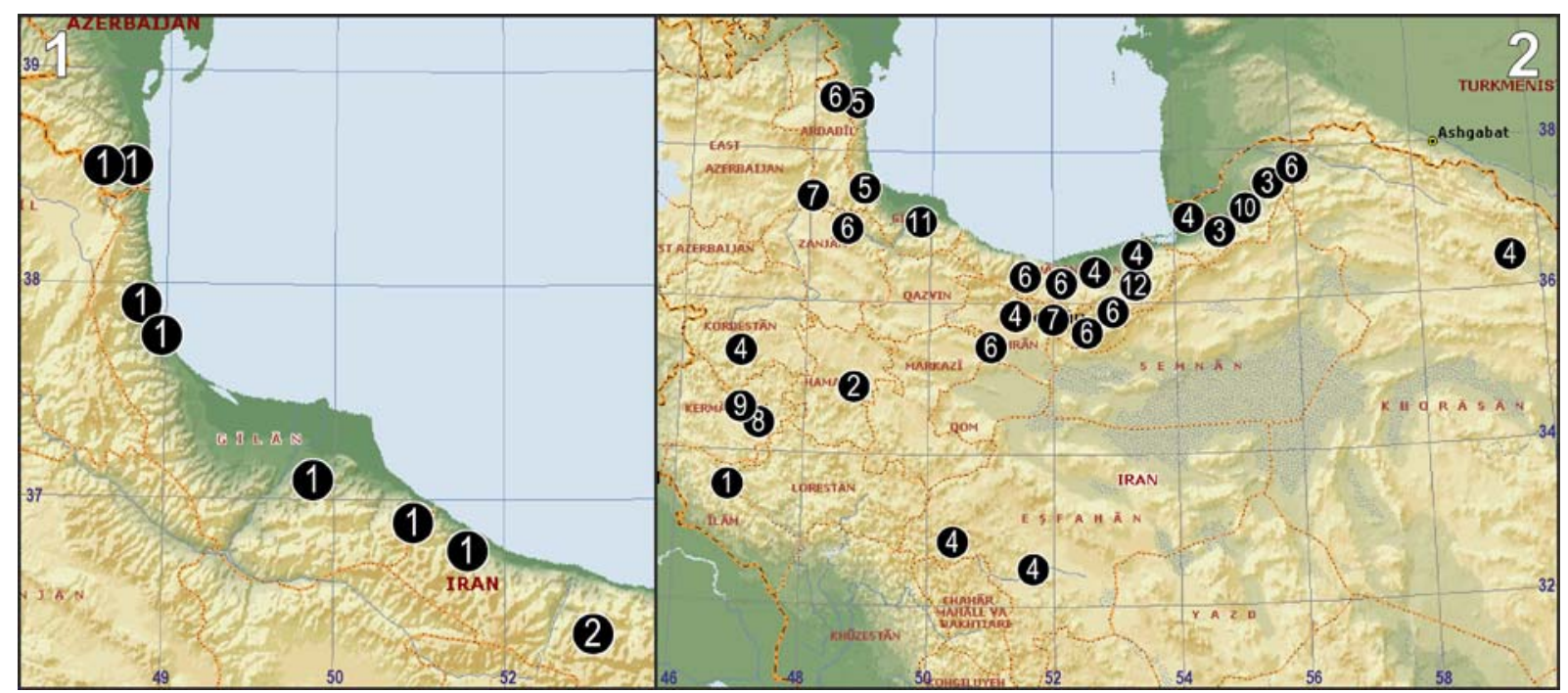

Maps 1-2. 1 - distribution of Azerithonica hyrcanica (1) and A. sagartia sp.n. (2). 2 - distribution of Tegenaria spp. occurring in Iran: 1 - T. alamto; 2 - T. arsacia sp.n.; 3 - T. eros sp.n.; $4-$ T. domestica; $5-$ T. halidi; $6-$ T. lenkoranica; 7 - T. pagana; $8-$ T. guseinovi sp.n.; $9-$ T. shirin sp.n.; $10-$ T. zamanii; $11-$ T. daylamanica sp.n.; $12-$ T. rahnamayi sp.n. (Known Azerbaijani records of $T$. halidi and $T$. lenkoranica are also depicted).

Карты 1-2. 1 - распространение Azerithonica hyrcanica (1) и A. sagartia sp.n. (2). 2 - распространение Tegenaria обитающих в Иране: 1 - T. alamto; 2 - T. arsacia sp.n.; $3-$ T. eros sp.n.; $4-$ T. domestica; $5-$ T. halidi; $6-$ T. lenkoranica; 7 - T. pagana; 8 - T. guseinovi sp.n.; 9 - T. shirin sp.n.; $10-$ T. zamanii; $11-$ T. daylamanica sp.n.; $12-$ T. rahnamayi sp.n. Показаны также находки T. halidi и T. lenkoranica в Азербайджане.

DESCRIPTION. Described by Zamani et al. [2018a]. RECORDS IN IRAN. Ilam [Zamani et al., 2018a].

DISTRIBUTION. Known only from the type locality in Barreh Zard Cave, western Iran (Map 2).

\section{Tegenaria arsacia sp.n.}

Figs 1A, 5A-D, Map 2.

TYPE MATERIAL. Holotype + (NHMG), Iran: Hamedan Province: Hamedan, $34^{\circ} 44^{\prime} \mathrm{N}, 48^{\circ} 47^{\prime} \mathrm{E}, 2600 \mathrm{~m}, 16.06 .1975$ (A. Senglet).

ETYMOLOGY. This species is named after Arsaces I, the first king of the Parthian Empire, as well as the founder and eponym of the Arsacid Dynasty of Parthia.

DIAGNOSIS. This species differs from congeners occurring in Iran by elongate and twisted-around-axis tubular receptacles (left receptacle S-shaped, Figs 5B-C) and long, membranous copulatory ducts. Other species have either globular receptacles, or that are not twisted, or have no distinct copulatory ducts.

DESCRIPTION. Female. Total length 4.61. Carapace 2.29 long, 1.65 wide. Eye sizes and interdistances: AME: 0.09, ALE: 0.11, PME: 0.13, PLE: 0.12, PME-PME: 0.10. Carapace, sternum, labium, chelicerae, and maxillae light brown. Carapace with two dark brown marginal bands and a thin brown line encircling the margins. Sternum with a light median band and six light patches in the margins, surrounded by a light grey pattern. Legs with faded annulations, consisting of patterns of light and dark brown. Abdomen light yellowish without any pattern. Spinnerets yellowish. Leg I measurements: 14.24 (2.71, 0.94, 2.57, 2.62, 1.40).

Epigyne as in Figs 5A-D. Fovea and copulatory openings indistinct, teeth absent. Anterior part with transverse ridge. Receptacles tubular, twisted around their axis. Copulatory ducts weakly sclerotized, indistinct on unstained epig- yne, C-shaped, as long as anterior part of receptacle; boundary of copulatory duct and receptacle with gland $(R g)$.

Male. Unknown.

DISTRIBUTION. Known only from the type locality in Hamedan Province, northwestern Iran (Map 2).

\section{Tegenaria daylamanica sp.n. Figs 1F, 6I-J, Map 2.}

TYPE MATERIAL. Holotype $q$ (NHMG), Iran: Gilan Province: Lunak, $37^{\circ} 03^{\prime} \mathrm{N}, 49^{\circ} 55^{\prime} \mathrm{E}, 600 \mathrm{~m}, 6.07 .1973$ (A. Senglet)

ETYMOLOGY. The specific epithet refers to Daylam, also known in the plural form Daylaman, which is the historical name of a mountainous region of inland Gilan, Iran.

DIAGNOSIS. This species is somewhat similar to $T$. eros sp.n., but differs by the shape of the epigynal fovea ("heart"-shaped in T. eros sp.n. vs. semicircular in T. daylamanica sp.n.), and by the bilobed receptacles and longer copulatory ducts.

DESCRIPTION. Female. Total length 5.28. Carapace 2.01 long, 1.65 wide. Eye sizes and interdistances: AME: 0.07, ALE: 0.14, PME: 0.11, PLE: 0.12, PME-PME: 0.08. Carapace, sternum, labium, chelicerae, and maxillae light brown. Carapace with fade brown radiating lines, starting from fovea toward submargin. Sternum with a marginal ring of six continuous gray patches. Legs the same color as carapace, with indistinct annulations. Abdomen cream with indistinct darker patches on dorsum, and with similar longitudinal patterns on the ventral area. Spinnerets yellowish. Leg I measurements: 8.97 (2.43, 0.84, 2.16, 2.17, 1.37).

Epigyne as in Figs 6I-J. Outline of posterior margin triangular, fovea distinct and semicircular, teeth absent. Receptacles dumbbell-shaped, upper sections converging. Copulatory ducts well-sclerotized, long, terminating in the upper globular receptacle. 


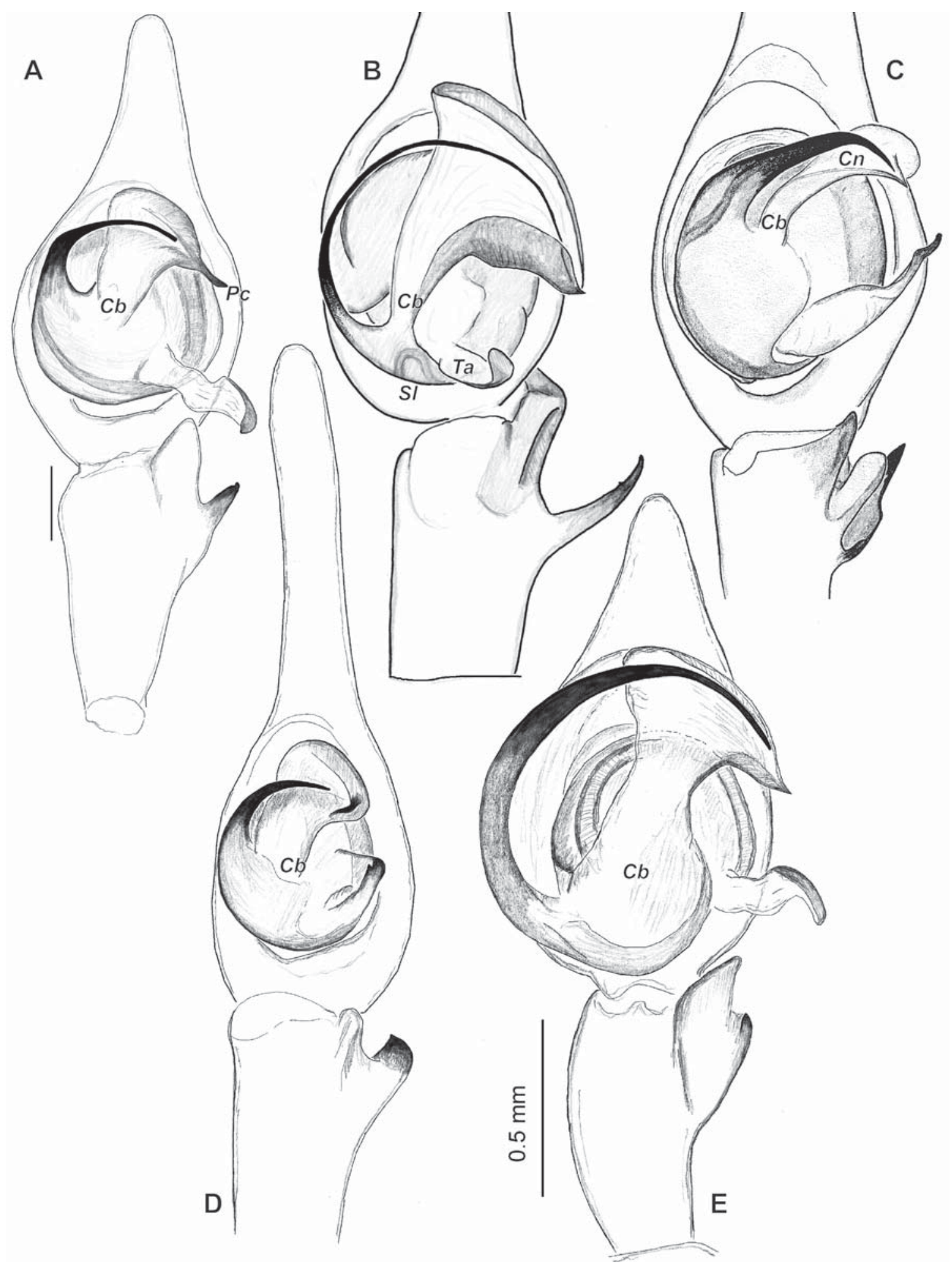

Fig. 3. Male palp, ventral view of Tegenaria alamto (A), T. lenkoranica (B), T. halidi (C), T. zamanii (D) and T. shirin sp.n. (E). B, C after Marusik et al. [2005].

Abbreviations: $\mathrm{Cb}$ - base of conductor, $\mathrm{Cn}$ - conductor, $\mathrm{Pc}$ - posterior branch of conductor, $\mathrm{Sl}$ - seminal loop, $\mathrm{Ta}$ - tegular apophysis.

Рис. 3. Пальпа самца, вид снизу Tegenaria alamto (A), T. lenkoranica (B), T. halidi (C), T. zamanii (D) и T. shirin sp.n. (E). B, C after Marusik et al. [2005].

Сокращения: $C b$ - основание кондуктора, $C n-$ кондуктор, $P c$ - задняя часть кондуктора, $S l$ - петля семенного канальца, $T a$ - тегулярный отросток. 


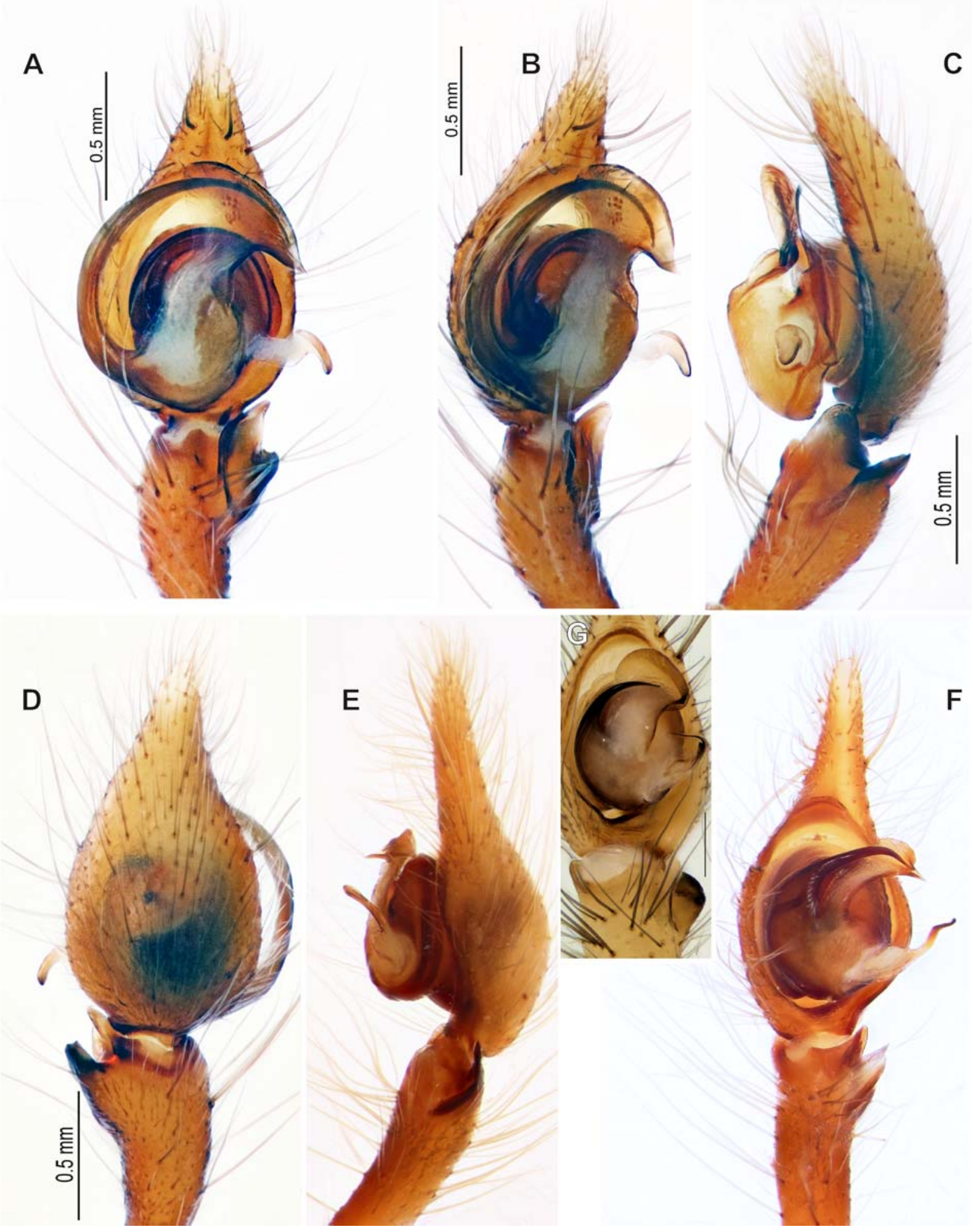

Fig. 4. Male palp of Tegenaria shirin sp.n. (A-D), T. halidi (E, F) and T. zamanii (G). A, F-G - ventral; B - ventro-prolateral; C, $\mathrm{E}$ - retrolateral; D - dorsal. Scale $=0.2 \mathrm{~mm}$, if not otherwise indicated.

Рис. 4. Пальпа самца Tegenaria shirin sp.n. (А-D), T. halidi (Е, F) и T. zamanii (G). A, F-G - снизу; В - снизу-пролатерально; C, Е - ретролатерально; D - сверху. Масштаб = 0,2 мм, если не указано иначе. 

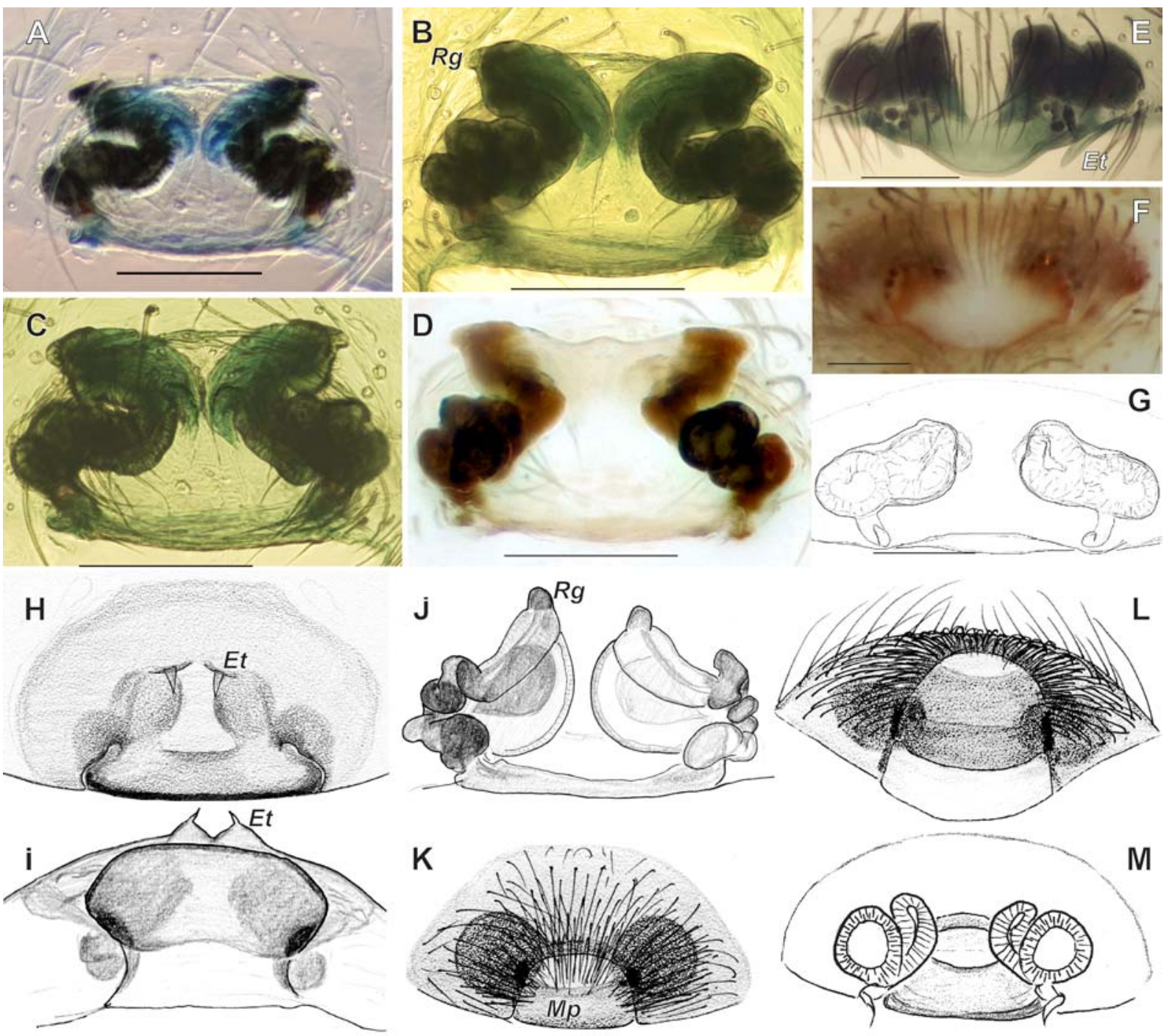

Fig. 5. Epigyne of Tegenaria arsacia sp.n. (A-D), T. alamto (E-G), T. lenkoranica (H-I) and T. halidi (J-M). A, C, F, H, K - ventral; B, D, G, J, M - dorsal; E - anterior, showing teeth; I, L — posterior. E-G - after Zamani et al. [2018a]; H-M - after Marusik et al. [2014]. Scale $=0.2 \mathrm{~mm}$, if indicated.

Abbreviations: $E t$ - epigynal tooth, $M p$ - median plate, $R g$ - receptacular gland.

Рис. 5. Эпигина Tegenaria arsacia sp.n. (A-D), T. alamto (E-G), T. lenkoranica (H-I) и T. halidi (J-M). A, C, F, H, K - снизу; В, $\mathrm{D}, \mathrm{G}, \mathrm{J}, \mathrm{M}$ - сверху; Е - спереди, показаны зубчики; I, L - сзади. E-G - по Zamani et al. [2018a]; H-M - по Marusik et al. [2014]. Масштаб = 0,2 мм, если указано.

Сокращения: $E t$ - зубчик эпигины, $M p$ - медиальная пластинка, $R g$ - железа рецептакулы.

Male. Unknown.

DISTRIBUTION. Known only from the type locality in Gilan Province, northern Iran (Map 2).

\section{Tegenaria domestica (Clerck, 1757) Map 2.}

Tegenaria domestica: Bolzern et al., 2013: 795, f. 1A-D, 2F, $16 \mathrm{~W}-\mathrm{X}, 17 \mathrm{~A}-\mathrm{B}, 18 \mathrm{~A}-\mathrm{C}\left(\mathrm{O}^{\top} \mathrm{O}\right)$.

For the complete list of taxonomic references see WSC [2019]. MATERIAL EXAMINED. Iran: Isfahan Province: $20^{7} 0^{7} 8$ o (NHMG), Daran, $32^{\circ} 58^{\prime} \mathrm{N}, 50^{\circ} 24^{\prime} \mathrm{E}, 22.06 .1974$ (A. Senglet).

COMMENTS. This is the type species of the genus, known from over 130 taxonomic publications [WSC, 2019]. Therefore, we do not provide figures for this species.
RECORDS IN IRAN. Golestan, Isfahan, Kordestan, Mazandaran, Razavi Khorasan, Tehran [Ghahari, Marusik, 2009; Ghahari, Tabari, 2012; Zamani, 2016] (Map 2).

DISTRIBUTION. Tegenaria domestica is a synanthropic species distributed across the entire Palaearctic. It is introduced to Americas, New Zealand and Australia [WSC, 2019]. In Iran, the species also occurs in natural habitats [Ghahari, Marusik, 2009; current data].

\section{Tegenaria eros sp.n.}

Figs 1C, 6A-F, 8A, Map 2.

TYPE MATERIAL. Holotype + (NHMG), Iran: Golestan Province: Gol-e Loveh, $37^{\circ} 20^{\prime} \mathrm{N}, 55^{\circ} 44^{\prime} \mathrm{E}, 700 \mathrm{~m}, 21.08 .1975$ (A. Sen- 

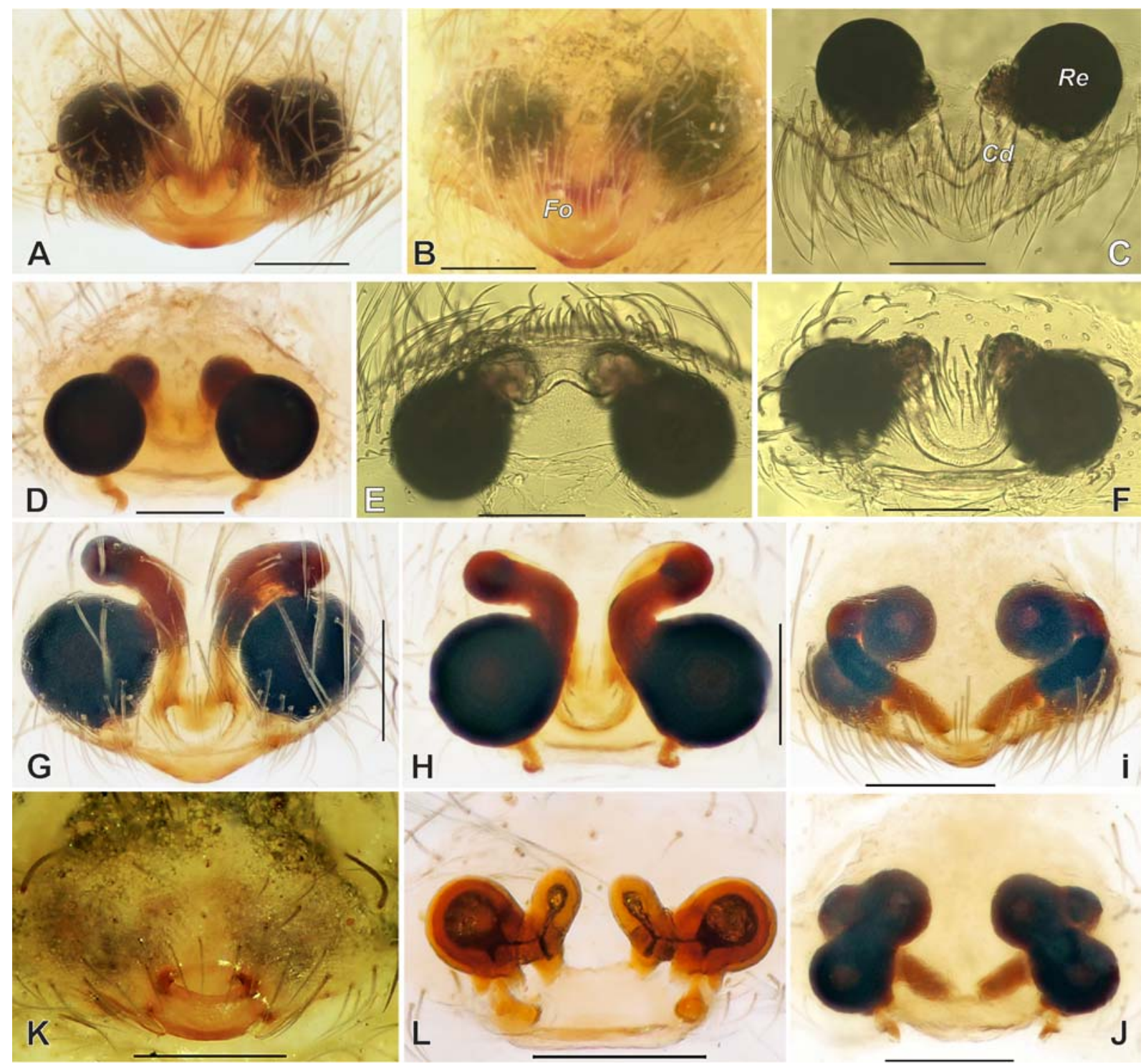

Fig. 6. Epigyne of Tegenaria eros sp.n. (A-F), T. rahnamayi sp.n. (G-H), T. daylamanica sp.n. (I-J) and T. zamanii (K-L). A-C, G, I, $\mathrm{K}$ - ventral; D, F, H, J, L - dorsal; E - anterior. K-L - after Marusik et al. [2014]. Scale = 0.2 mm.

Abbreviations: $C d$ - copulatory duct, $F o$ - fovea, $R e$ - receptacle.

Рис. 6. Эпигина Tegenaria eros sp.n. (A-F), T. rahnamayi sp.n. (G-H), T. daylamanica sp.n. (I-J) и T. zamanii (K-L). A-C, G, I, K снизу; D, F, H, J, L - сверху; Е - спереди. K-L — по Marusik et al. [2014]. Масштаб = 0,2 мм.

Сокращения: $C d$ - копулятивный канал, $F o$ - ямка, $R e$ - рецептакула.

glet). Paratypes: 2 +๑ (NHMG), Golestan Province: NaharkhoranGorgan, 36 $44^{\prime} \mathrm{N}, 5^{\circ} 29^{\prime} \mathrm{E}, 20.07 .1973$ (A. Senglet); 2 우 (NHMG), Tang-e Rah, $37^{\circ} 23^{\prime} \mathrm{N}, 55^{\circ} 50^{\prime} \mathrm{E}, 13.07 .1974$ (A. Senglet).

ETYMOLOGY. The specific epithet refers to Eros, the Greek god of love, as a reference to the "heart"-shaped epigynal fovea in this new species.

DIAGNOSIS. The new species well differs from all other congeners occurring in Iran (except $T$. rahnamayi sp.n.) by the pattern on the carapace (Fig. 1C): dark marginal stripes and 2 wide, dark longitudinal dark bands extending along the entire length of the carapace. In other species, the bands, if present, are less distinct (if present) and the marginal stripes are broken rather than continuous ( $T$. guseinovi sp.n.). The epigyne differs from other species by the "heart"-shaped fovea ( $v s$. fovea absent or transverse). It is somewhat similar to $T$. zamanii, from which it differs by the lack of epigynal teeth, and a fovea that is not transverse. It differs from the closely related $T$. rahnamayi sp.n. by the much shorter and straight copulatory ducts (longer and coiled in the other species).

DESCRIPTION. Female (holotype). Total length 6.74. Carapace 3.06 long, 2.20 wide. Eye sizes and interdistances: AME: 0.09, ALE: 0.18, PME: 0.15, PLE: 0.16, PME-PME: 0.13. Carapace, sternum, labium, chelicerae, and maxillae light brown. Carapace with two dark brown marginal bands and a thin brown line encircling the margins. Sternum with a light median band and six light patches in the margins, surrounded by a light grey pattern. Legs with distinct annulations, of light and dark brown. Abdomen cream colored with distinct dark gray patches on dorsum and with similar 

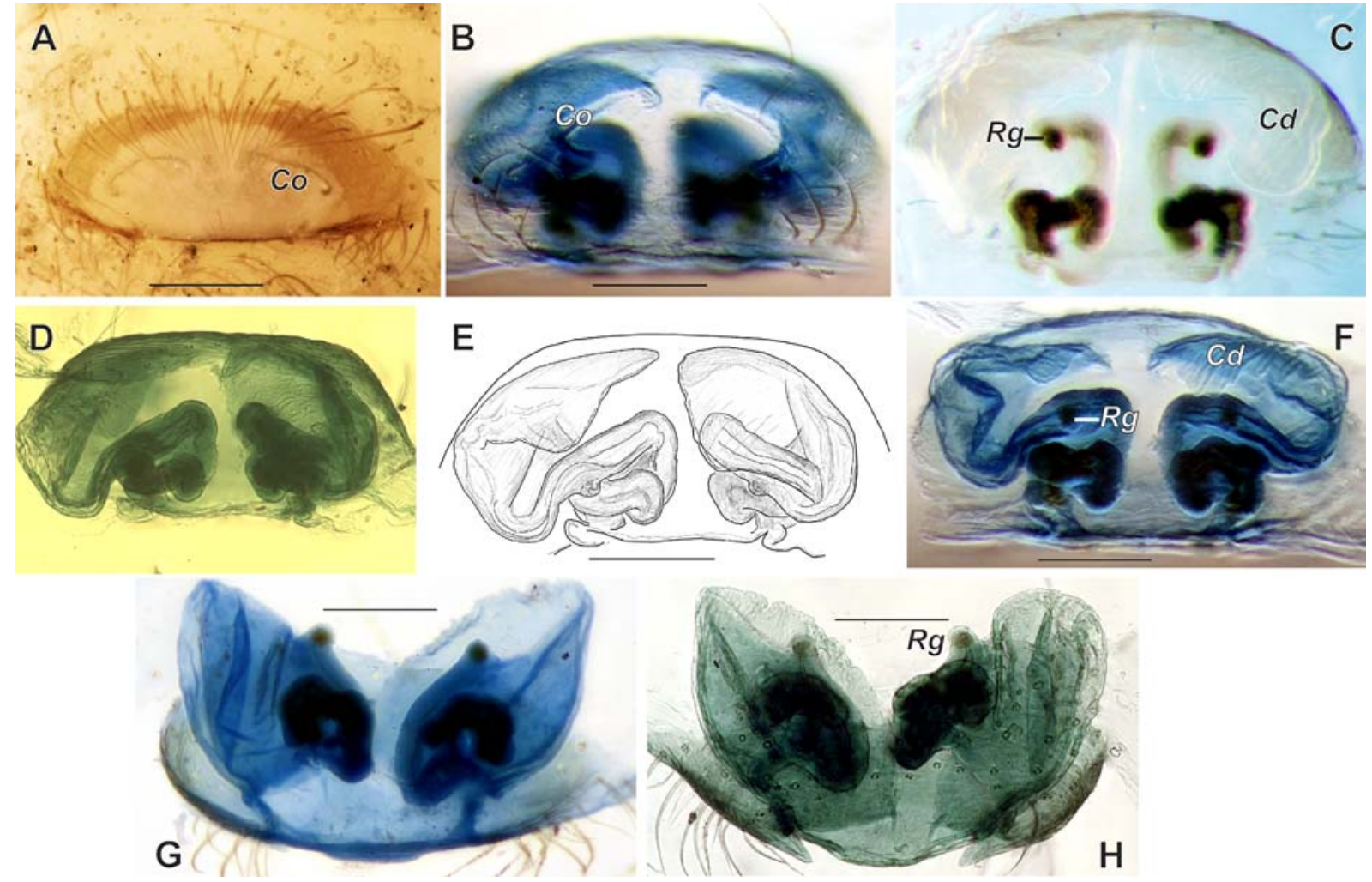

Fig. 7. Epigyne of Tegenaria guseinovi sp.n. A — intact, ventral; B — ventro-posterior; C — dorsal; D-E - ventro-anterior; F dorso-anterior; G-H - posterior. B, D-H - macerated; C - uncolored.

Abbreviations: $C d$ - copulatory duct, $C o$ - copulatory opening, $R g$ - receptacular gland.

Рис. 7. Эпигина of Tegenaria guseinovi sp.n. А - интактная, снизу; В — снизу-сзади; C - сверху; D-E - снизу-спереди; F сверху-спереди; G-H - сзади. В, D-H - мацерированная; C - неокрашенная.

Сокращения: $C d$ - копулятивный канал, $C o$ - копулятивное отверстие, $R g$ - железа рецептакулы.

longitudinal patterns on the ventral area. Spinnerets yellowish, with light grey patches on the anterior ones. Leg I measurements: $14.24(3.7,1.24,3.51,3.58,2.21)$.

Epigyne as in Figs 6A-F. Outline of posterior margin triangular, fovea distinct, "heart"-shaped, teeth absent. Receptacles globular with small semicircular outgrowth directed ventro-mesally. Receptacles separated by about 0.7 diameters. Copulatory ducts weakly sclerotized, straight, about 2/ 3 of receptacle diameter.

Male. Unknown.

DISTRIBUTION. Known only from the type localities in Golestan Province, northern Iran (Map 2).

\section{Tegenaria guseinovi sp.n.} Figs 1E, 7A-H, Map 2.

TYPE MATERIAL. Holotype $q$ and paratypes 2 우 1 juv. (NHMG), Iran: Kermanshah Province: around Kermanshah, $34^{\circ}$ $24^{\prime} \mathrm{N}, 47^{\circ} 10^{\prime} \mathrm{E}, 30.6 .1974$ (A. Senglet).

ETYMOLOGY. The species is named after our friend and colleague Elchin Guseinov (Elçin Hüseynov in Azerbaijani, Baku, Azerbaijan) in recognition of his numerous contributions to the study of spiders and particularly Agelenidae of Azerbaijan.

DIAGNOSIS. The new species well differs from other Tegenaria occurring in Iran by the transverse epigynal plate (2.2 wider than long) lacking a fovea but with long, trans- verse slit-like copulatory openings. Other species have either a fovea, or the fovea and copulatory organs are not transverse. It differs from all other Tegenariini by the presence of long, flat, membranous copulatory ducts with a gland and duct-like receptacle (vs. copulatory duct short, or cylindrical and lacking glands, receptacle globular or elongate).

DESCRIPTION. Female (holotype). Total length 8.06. Carapace 3.35 long, 2.55 wide. Eye sizes and interdistances: AME: 0.11, ALE: 0.18, PME: 0.15, PLE: 0.19, PME-PME: 0.15 . Carapace almost uniformly light brown with two faded darker longitudinal bands, and a slightly darker cephalic part. Legs without annulations. Abdomen light greyish with scattered dark grey patches dorsally. Spinnerets uniformly yellow. Leg I measurements: 21.08 (5.40, 1.50, 5.73, 6.14, 2.31).

Epigyne as in Figs $7 \mathrm{~A}-\mathrm{H}$. Plate 2.2 times wider than long, lacking fovea; copulatory openings long, transverse, slit-like, separated by about $2 / 3$ their length; small posterior teeth present, but indistinct in intact epigyne. Endogyne very complex, with wide and flat membranous copulatory ducts $(C d)$ forming several folds that are indistinct in an uncolored epigyne (Fig. 7C). Receptacle (Re) duct-like, bent 4 times, and the border between the duct and receptacle with a gland $(R g)$.

Male. Unknown.

COMMENTS. Although T. guseinovi sp.n. (known only from the female) and T. shirin sp.n. (known only from the male) were collected from two nearby localities, we do not 

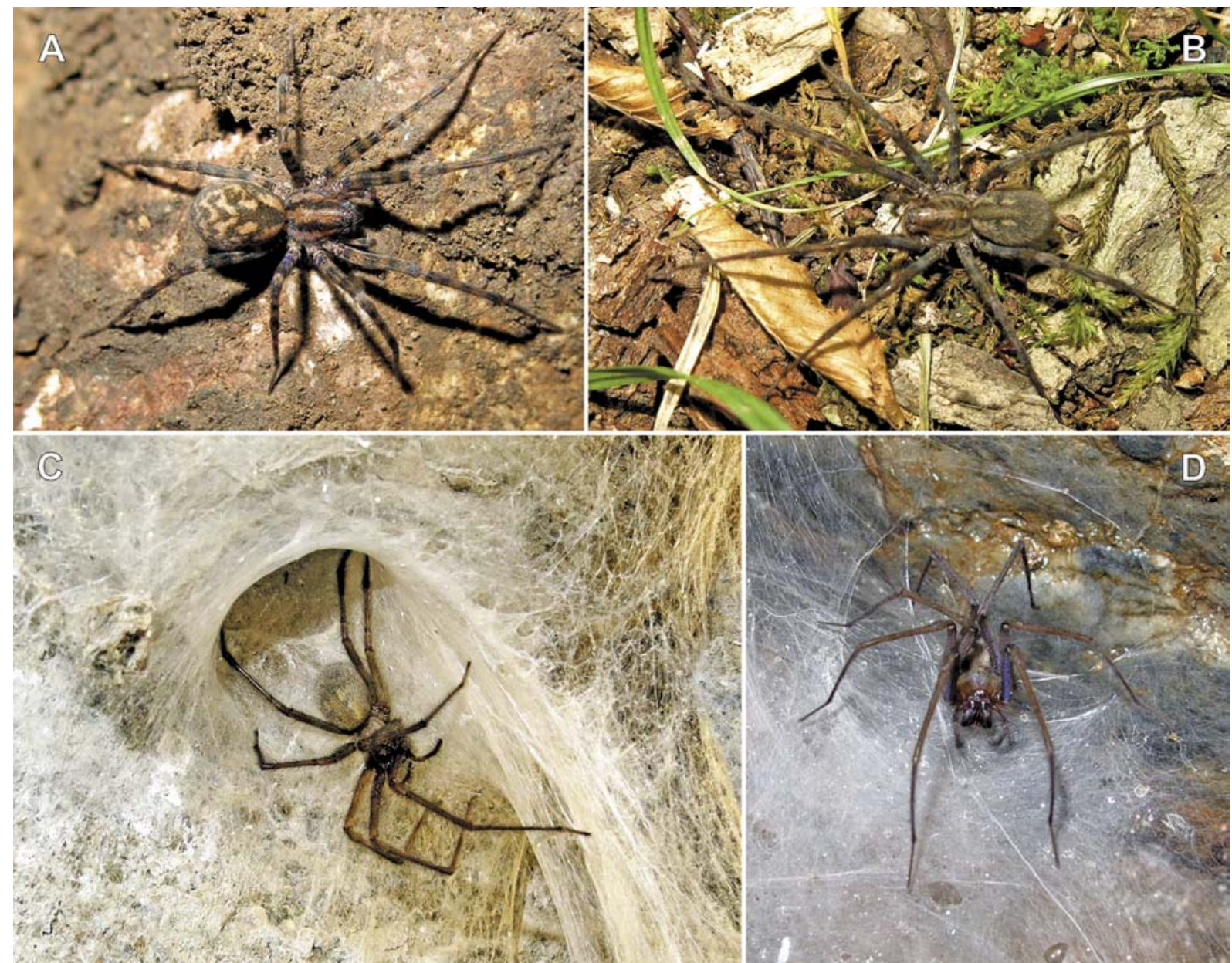

Fig. 8. Live habitus of Tegenaria eros sp.n. (A), T. lenkoranica (B-C) and T. zamanii (D). Photos by A. Zamani.

Рис. 8. Прижизненные фотографии Tegenaria eros sp.n. (A), T. lenkoranica (B-C) и T. zamanii (D). Фотографии A. Zamani.

believe that they belong to the same species: T. shirin sp.n. is very similar to T. epacris Levy, 1996 (Israel), but the endogyne of $T$. guseinovi sp.n. differs drastically from those of $T$. epacris as well as other Tegenariini. Notably, the presence of a gland on the boundary of the copulatory duct and the duct-like receptacle and broad and flat copulatory ducts are also known in T. lenkoranica (Fig. 5J); however, the shape of the epigyne is very different between these two species.

DISTRIBUTION. Known only from the type locality in Kermanshah Province, western Iran (Map 2).

\section{Tegenaria halidi Guseinov, Marusik et Koponen, 2005}

Figs 3C, 5K-M, Map 2.

Tegenaria halidi Guseinov et al., 2005: 174, f. 52, 90-92,

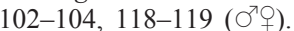

MATERIAL EXAMINED. Iran: Gilan Province: $20^{7} 0^{7} 6$ OO (NHMG), Pareh-Sar, 37³7'N, 490'ㄹ, 2.07.1973 (A. Senglet).

DIAGNOSIS. Males of $T$. halidi well differ from other Tegenaria species occurring in the Middle East by the very short, tapering embolus and the long, tapering tegular apophysis which is the same length as the embolus. Other species have either an embolus that is longer than the tegular apophysis or an embolus and tegular apophysis that do not taper. The male palp of this species is similar to $T$. domesti$c a$ (short embolus, long tegular apophysis) but differs by the very elongate conductor which lacks any kind of prolateral arm. Females of $T$. halidi are similar to those of $T$. zamanii by having a transverse fovea and a median plate, globular receptacles and by the shape of copulatory ducts (cf. Figs $5 \mathrm{~K}, \mathrm{M}$ and Figs $6 \mathrm{~K}-\mathrm{L}$ ), lack of epigynal teeth and dense setae covering the fovea.

DESCRIPTION. Described by Guseinov et al. [2005].

RECORDS IN IRAN. Gilan (current data).

DISTRIBUTION. This species is known from southeastern Azerbaijan and the adjacent Gilan Province of Iran (first record) (Map 2).

\section{Tegenaria lenkoranica (Guseinov, Marusik} et Koponen, 2005)

Figs 3B, 5H-J, 8B-C, Map 2.

Malthonica lenkoranica Guseinov et al., 2005: 164, f. 48, 50, 85-87, 116-117, 121 ( $\mathrm{O}^{7}+$ ).

MATERIAL EXAMINED. Iran: Gilan Province: $20^{7} \sigma^{7} 6$ 우 (NHMG), Pareh-Sar, 37³7'N, 49 $03^{\circ} \mathrm{E}, 2.07 .1973$ (A. Senglet); Golestan Province: 1 ( $\mathrm{NHMG}$ ), Naharkhoran-Gorgan, $36^{\circ} 44^{\prime} \mathrm{N}$, $54^{\circ} 29^{\prime} \mathrm{E}, 20.07 .1973$ (A. Senglet); 1 O (NHMG), Tang-e Rah, $37^{\circ}$ $25^{\prime} \mathrm{N}, 55^{\circ} 45^{\prime} \mathrm{E}, 28.07 .1974$ (A. Senglet); 1 \& (NHMG), Tang-e Rah, $37^{\circ} 23^{\prime} \mathrm{N}, 55^{\circ} 50^{\prime} \mathrm{E}, 13.07 .1974$ (A. Senglet); Mazandaran 
Province: 1 ㅇ (NHMG), Razan, $36^{\circ} 12^{\prime} \mathrm{N}, 52^{\circ} 08^{\prime} \mathrm{E}, 1500 \mathrm{~m}, 8.07$.

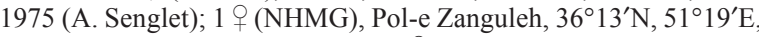
$2300 \mathrm{~m}, 10.07 .1974$ (A. Senglet); 1 ㅇ (NHMG), Baladeh, $36^{\circ} 13^{\prime} \mathrm{N}$

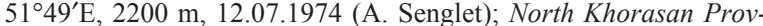
ince: near Dasht, $37^{\circ} 23^{\prime} \mathrm{N}, 5^{\circ} 13^{\prime} \mathrm{E}, 1600 \mathrm{~m}, 17.07 .1975$ (A. Senglet); Tehran Province: 10 OQ 1 juv. (ZMMU), $\sim 80 \mathrm{~km} \mathrm{E}$ of Tehran, Damavand area, Aroo Vil., 35 $40^{\prime} \mathrm{N}, 52^{\circ} 27^{\prime} \mathrm{E}, 15.06 .2000$ (Yu.M. Marusik, F. Mozaffarian).

DIAGNOSIS. Males of $T$. lenkoranica differs from congeners by the very thin base of the conductor (10 times thinner than the terminal part), by having the loop of the sperm duct near the base of the conductor and the very long and elongate retrolateral tibial apophysis (as long as the tibia diameter). Other species have a conductor base that is less than 3 times thinner than the terminal part, have no sperm duct loop and have no long and elongate tibial apophysis. Females differ from other Tegenariini by having anterior epigyne teeth ( $v s$. no teeth or teeth located posteriorly, bordering the median plate). Both sexes of $T$. lenkoranica differ from other Iranian species, except $T$. pagana, by their large size (over $10 \mathrm{~mm}$ ).

DESCRIPTION. Described by Guseinov et al. [2005].

COMMENTS. Judging from the unique shape of the male palp (thin conductor base, sperm duct loop, elongate tibial apophysis) and especially the epigyne with its anterior teeth, it is very likely that this species could be placed in a separate genus.

RECORDS IN IRAN. Alborz, Golestan, Mazandaran, Tehran, Zanjan [Zamani et al., 2014, 2018b; Zamani, 2016; Malek-Hosseini, Zamani, 2017], Gilan, North Khorasan (current data).

DISTRIBUTION. The species is known from southeastern Azerbaijan to northeastern Iran (Map 2).

$$
\begin{gathered}
\text { Tegenaria pagana C.L. Koch, } 1840 \\
\text { Map } 2 .
\end{gathered}
$$

Tegenaria pagana: Bolzern et al., 2013: 805, f. 23K-W ( $\left.\bigcirc^{7}+\right)$. 2019].

For the complete list of 56 taxonomic references see WSC

MATERIAL EXAMINED. Iran: East Azarbayjan Province: 1 (NHMG), road to Miyaneh, 372 $21^{\prime} \mathrm{N}, 47^{\circ} 49^{\prime} \mathrm{E}, 11.07 .1974$ (A Senglet); Tehran Province: 1 क (ZMMU), Tehran, Evin, 18.03.1998 (collector unknown).

COMMENTS. This widespread species is well known due to numerous publications. Males of this species well differ from other species known from Iran by having a welldeveloped prolateral arm of the conductor ( $v s$. lacking).

RECORDS IN IRAN. Tehran [Zamani et al., 2014; Zamani, 2016], East Azarbayjan (current data) (Map 2).

DISTRIBUTION. This species is known from Europe to the western part of Central Asia. It is introduced to the USA, Mexico, Brazil, and Chile [WSC, 2019].

\section{Tegenaria rahnamayi sp.n. Figs 1G, 6G-H, Map 2.}

TYPE MATERIAL. Holotype + (NHMG), Iran: Mazandaran Province: Kiyasar, $36^{\circ} 16^{\prime} \mathrm{N}, 53^{\circ} 25^{\prime} \mathrm{E}, 10.07 .1975$ (A. Senglet).

ETYMOLOGY. This species is named after Mr. Omid Rahnamay, the high school biology teacher of the senior author, who encouraged him to pursue natural sciences in an academic level.

DIAGNOSIS. This species is closely related to T. eros sp.n. by the habitus, having a similarly shaped epigynal fovea and globular receptacles, but can be separated by the coiled and considerably longer copulatory ducts (longer than receptacle vs. much shorter) and less separated receptacles (ca 1 radius $v s .1 .5$ radius).

DESCRIPTION. Female. Total length 4.56. Carapace 2.04 long, 1.47 wide. Eye sizes and interdistances: AME: 0.07, ALE: 0.12, PME: 0.10, PLE: 0.11, PME-PME: 0.10. Carapace, sternum, labium, chelicerae and maxillae light brown. Carapace with two dark brown marginal bands and a thin brown line encircling the margins. Sternum with a light median band and six light patches in the margins, surrounded by a light grey pattern. Legs with distinct annulations of alternating light and dark brown. Abdomen cream colored with distinct dark gray patches on dorsum, and with similar longitudinal patterns ventrally. Spinnerets yellowish. Leg I measurements: 7.86 (2.06, 0.78, 1.87, 1.88, 1.27).

Epigyne as in Figs $6 \mathrm{G}-\mathrm{H}$. Outline of posterior margin triangular, fovea distinct, "heart"-shaped, teeth absent. Receptacles globular with small semicircular outgrowth directed ventro-mesally, separated by about one receptacle radius. Copulatory ducts longer than receptacle diameter, basal part (near receptacle) relatively well-sclerotized, forming a small coil above the receptacles.

Male. Unknown.

DISTRIBUTION. Known only from the type locality in Mazandaran Province, northern Iran (Map 2).

\section{Tegenaria shirin sp.n.} Figs 1D, 3E, 4A-D, Map 2.

TYPE MATERIAL. Holotype $\sigma^{7}$ (NHMG), Iran: Kermanshah Province: SE of Kermanshah, $34^{\circ} 33^{\prime} \mathrm{N}, 4^{\circ} 02^{\prime} \mathrm{E}, 12.09 .1975$ (A. Senglet).

ETYMOLOGY. The specific epithet refers to the main female character of "Khosrow and Shirin", a famous Persian tragic romance by the poet Nizami Ganjavi (1141-1209).

DIAGNOSIS. The new species well differs from congeners in Iran by the thick and long embolus (longer than cymbium, Figs 3E, 4A) vs. an embolus either shorter than the cymbium (Figs 3A, C-D) or a filamentous embolus (Fig. 3B). The male palp of T. shirin sp.n. is most similar to those of T. epacris Levy, 1996 from Israel by having a long embolus and tegular apophysis as well as by the shape of the retrolateral arm of the conductor; however, it differs by having a thick embolus ( $v s$. filamentous) and lacks a prolateral arm of the conductor ( $v s$. a well-developed prolateral arm, cf. fig. 54 in Levy, 1996).

DESCRIPTION. Male. Total length 6.55. Carapace 3.08 long, 2.47 wide. Eye sizes and interdistance: AME: 0.12, ALE: 0.17, PME: 0.15, PLE: 0.15, PME-PME: 0.13. Carapace, sternum, labium, chelicerae, and maxillae light brown (Fig. 1D). Carapace slightly darker in pars cephalica, without any pattern. Legs the same color as the carapace and without annulations, with long white setae on the femora. Abdomen cream colored with distinct dark gray patches on dorsum and without any pattern ventrally. Spinnerets uniformly colored and the same color as the abdomen. Leg I measurements: $24.01(6.47,1.40,6.66,6.81,2.67)$.

Palp as in Figs 3E, 4A-D. Relatively short, tibia 2 times shorter than cymbium, ventrolateral tibial apophysis $(V l)$ long, about $1 / 2$ tibia length. Cymbium droplet-shaped, almost 2 times longer than wide; tegular apophysis long, about 3 times longer than wide, as wide as embolic base; conductor with wide base, prolateral arm not developed, retrolateral arm sharply pointed; embolus long and wide, slightly longer (ca. 1.14) than cymbium, starting at 7.5 o'clock position. 
Female. Unknown.

DISTRIBUTION. Known only from the type locality in Kermanshah Province, western Iran (Map 2).

Tegenaria zamanii Marusik et Omelko, 2014 Figs 3D, 4G, 6K-L, 8D, Map 2.

Tegenaria zamanii Marusik et Omelko, in Marusik et al., 2014: 256, f. 1a-1, 2a-e (+).

Tegenaria zamanii: Marusik, Zamani, 2015: 226, f. 1-7 ( $\left(^{7}\right)$.

DIAGNOSIS. Males of this species well differ from other species occurring in the Middle East by having a very long cymbium (tip 2 times longer than bulb vs. shorter than bulb). Epigyne in T. zamanii is similar to those of T. eros sp.n. and T. domestica. From the former species it differs by the transverse fovea and the presence of epigynal teeth (vs. "heart"-shaped fovea and no epigynal teeth). From the generotype, $T$. domestica, $T$. zamanii differs by having a narrower median plate ( 2 times wider than long $v s$. more than 3 times wider than long).

DESCRIPTION. Described by Marusik et al. [2014] and Marusik \& Zamani [2015].

RECORDS IN IRAN. Golestan [Marusik et al., 2014; Marusik, Zamani, 2015].

DISTRIBUTION. Known only from the type locality in Shirabad Cave, northeastern Iran (Map 2).

Acknowledgments. We are grateful to Peter J. Schwendinger (Muséum d'histoire naturelle, Genève) for sending us the material collected by the late A. Senglet, Seppo Koponen and Ilari Sääksjärvi (Zoological Museum, University of Turku) for allowing us to use museum facilities, and to anonymous reviewers for valuable comments. The English in the final draft was kindly checked by Sarah Crews.

\section{References}

Bolzern A., Burckhardt D., Hänggi A. 2013. Phylogeny and taxonomy of European funnel-web spiders of the Tegenaria-Malthonica complex (Araneae: Agelenidae) based upon morphological and molecular data // Zoological Journal of the Linnean Society. Vol.168. P.723-848.

Brignoli P.M. 1972. Terzo contributo alla conoscenza dei ragni cavernicoli di Turchia (Araneae) // Fragmenta Entomologica. Vol.8. P.161-190.

Brignoli P.M. 1978a. Ragni di Turchia IV. Leptonetidae, Dysderidae ed Agelenidae nuovi o interessanti di grotte della Turchia meridionale (Araneae) // Quaderni di Speleologia, Circolo Speleologico Romano. Vol.3. P.37-54.
Brignoli P.M. 1978b. Ragni di Turchia V. Specie nuove o interessanti, cavernicole ed epigee, di varie famiglie (Araneae) // Revue Suisse de Zoologie. T.85. P.461-541.

Ghahari H., Marusik Y.M. 2009. New data on spider fauna of Iran (Araneae) // Turkish Journal of Arachnology. Vol.2. P.1-8.

Ghahari H., Tabari M. 2012. [Fauna and population fluctuations of spiders (Arthropoda: Araneae) in rice fields of Mazandaran Province] // Journal of Plant Protection. Vol.26. No.2. P.136144 [in Persian].

Guseinov E., Marusik Yu.M., Koponen S. 2005. Spiders (Arachnida: Aranei) of Azerbaijan 5. Faunistic review of the funnelweb spiders (Agelenidae) with the description of a new genus and species // Arthropoda Selecta. Vol.14. P.153-177.

Levy G. 1996. The agelenid funnel-weaver family and the spider genus Cedicus in Israel (Araneae, Agelenidae and Cybaeidae) // Zoologica Scripta. Vol.25. No.2. P.85-122.

Malek-Hosseini M.J., Zamani A. 2017. A checklist of subterranean arthropods of Iran // Subterranean Biology. Vol.21. P.19-46.

Marusik Yu.M., Nadimi A., Omelko M.M., Koponen S. 2014. First data about cave spiders (Arachnida: Araneae) from Iran // Zoology in the Middle East. Vol.60. No.3. P.255-266.

Marusik Yu.M., Zamani A. 2015. First description of the male of Tegenaria zamanii Marusik \& Omelko, 2014 from Iran (Araneae: Agelenidae) // Zootaxa. Vol.4052. No.2. P.226-228.

Mikhailov K.G. 2013. The spiders (Arachnida: Aranei) of Russia and adjacent countries: a non-annotated checklist // Arthropoda Selecta. Suppl.3. P.1-262.

Otto S. 2014. Caucasian Spiders. A faunistic database on the spiders of the Caucasus. Version 1.4. Internet: http://caucasusspiders.info/

WSC. 2019. World Spider Catalog. Version 20.0. Natural History Museum Bern, online at http://wsc.nmbe.ch, accessed on $14^{\text {th }}$ of February, 2019.

Zamani A. 2016. The Field Guide of Spiders and Scorpions of Iran. Iranshenasi, Tehran, 360 pp. [In Persian]

Zamani A., Nikmagham Z., Allahdadi M., Ghassemzadeh F., Mirshamsi O. 2014. New data on the spider fauna of Iran (Arachnida: Araneae) // Zoology in the Middle East. Vol.60. No.4. P.362-367.

Zamani A., Marusik Yu.M., Malek-Hosseini M.J. 2018a. A new species of Tegenaria Latreille, 1804 (Araneae: Agelenidae) from western Iran // Zootaxa. Vol.4444. No.1. P.95-97.

Zamani A., Mirshamsi O., Kashani G.M., Karami L. 2018b [for 2017]. New data on the spider fauna of Iran (Arachnida: Araneae), Part V // Iranian Journal of Animal Biosystematics. Vol.13. No.2. P.183-197.

Zamani A., Mirshamsi O., Marusik Yu.M., Moradmand M. 2019. The Checklist of the Spiders of Iran. Version 2019, Online at http://www.spiders.ir

Responsible editor K.G. Mikhailov 